\title{
RETHINKING THE CONCEPT OF CONSENT IN INTERNATIONAL COMMERCIAL ARBITRATION: A GENERAL THEORY FOR NON-SIGNATORIES
}

\author{
Stavros Brekoulakis*
}

\begin{abstract}
This article is concerned with the role and relevance of non-signatories in international commercial arbitration. The article challenges the efficacy and coherence of the existing arbitration law in this area, and questions whether the traditional concept of consent for arbitration can be reconciled with complex commercial reality and non-signatories today. Instead, the article submits that a general theory on non-signatories is needed, and proposes that the theoretical basis for finding that non-signatories have rights or obligations in an arbitration should be shifted from the concept of consent to the concept of a 'dispute'.
\end{abstract}

Keywords: international commercial arbitration, non-signatories, consent, contract law theory, group of companies, commercial reality.

\section{INTRODUCTION: NON-SIGNATORIES AND CONTEMPORARY INTERNATIONAL COMMERCE}

This article is concerned with the role and relevance of non-signatories in international commercial arbitration. Non-signatory is a party that has not formally entered into an arbitration agreement, although it is implicated in a dispute which is the subject matter of an arbitration. In spite of voluminous academic literature, court decisions and arbitral awards, the debate on nonsignatories remains largely unsettled and has become one of the most pervasive issues in the field of international commercial arbitration. ${ }^{1}$ This article challenges the efficacy and coherence of the existing arbitration law and instead proposes a new unifying theory for non-signatories.

In litigation, parties whose legal interests are directly affected by the resolution of a dispute have the right to standing in the court proceedings. By

\footnotetext{
Professor in International Arbitration and Commercial Law, Centre for Commercial Law Studies, Queen Mary University of London. I would like to thank Catherine Rogers, S.I. Strong, Luke Nottage, Alan Rau and Christian Koller for their very helpful comments in an earlier draft of the article. I would also like to thank Ahmed El Far for his excellent research assistance. (email: s.brekoulakis@qmul.ac.uk).

${ }^{1}$ See M Blessing, 'Extension of the Arbitration Clause to Non-Signatories', in Arbitration Agreement: Its Multifold Critical Aspects (1999) 8 ASA Special Series 161; P Martines-Fraga 'The Dilemma of Extending International Commercial Arbitration Clauses to Third Parties: Is Protecting Federal Policy While Accommodating Economic Globalization a Bridge to Nowhere?', (2013) 46 Cornell Int'l L.J. 291; B Hanotiau, Complex Arbitrations: Multiparty, Multicontract, Multi-issue, and Class Actions (Kluwer 2003); A Steingruber, Consent in International Arbitration (OUP 2012).
} 
contrast, whether a party is able or obliged to participate in an arbitration depends on whether such party has previously entered into a valid arbitration contract. Any legal or financial interest that a party may have in the outcome of an arbitration cannot assist it to participate and protect its interests.

Traditionally, its consensual underpinnings made arbitration a flexible and popular method for resolving disputes especially in bilateral transactions, such as sales of goods and transport contracts. ${ }^{2}$ However, the contractual and bilateral nature of arbitration is often unable to accommodate modern business transactions that are typically multifaceted, multiparty and multi-contract.

The increasing complexity of contemporary international commerce is particularly evident in areas such as construction contracts, maritime contracts, merger and acquisition transactions, banking and financial transactions, joint venture agreements, supply chain contracts, insurance and reinsurance contracts, and transactions with states operating through a wide range of state entities and instrumentalities. Similarly, a large number of international business transactions involve multinational groups of companies, which nowadays tend to adopt corporate structures that are more sophisticated than the linear parentsubsidiary type of organization. Corporate groups may take the form of groups based on contract or equity, joint ventures between independent firms, informal alliances, publicly owned multinationals, and supranational forms of international business. ${ }^{3}$

The unprecedented scale of sophistication of international commerce presents crucial challenges for international commercial arbitration today and tests its traditional role and contractual nature to its limits.

How should we treat, for example, a State that sets up an instrumentality to sign a contract, including an arbitration clause, which the State negotiated in the first place? What should happen if the State is clearly implicated in the performance of the contract and the instrumentality (conveniently) ceases to exist by the time a dispute arises? Can the claimant bring the non-signatory State before an arbitral tribunal, or does it have to settle for the rather unappealing prospect of bringing a claim against the State before the State's own courts?

Similarly, how should we deal with disputes arising out of transactions with multinational groups of companies? Adopting a corporate group structure can be a very effective mode of corporate organisation and operation, which allows multinationals to rationalise the division of tasks and labour within the group. However, in practice, only the company that signs the contract (typically a subsidiary or a special purpose vehicle with limited funds), containing an arbitration agreement, will have a standing to participate in the arbitration. Nonsignatory companies of the same group will typically be excluded from arbitration proceedings, irrespective of whether they have been involved in the underlying substantive transaction. But, if the notion of corporate group

\footnotetext{
2 See Derek Roebuck, Mediation and Arbitration in the Middle Ages (Holo Books 2013).

3 P Muchlinski, Multinational Enterprises and the Law (Blackwell 1999) 62.
} 
structure makes good commercial sense in practice, why does arbitration doctrine ignore it? Why is a parent company, for example, unable to bring a claim before an arbitral tribunal requesting damages suffered by the group as a whole? Equally, why is a claimant able to bring a signatory subsidiary (with limited or no available funds) before an arbitral tribunal but not the parent company too?

Businesspersons may be displeased to find out that commercial reality may have outgrown the idea of bilateral contractual arbitration, which tends to exclude non-signatory parties from the arbitration process, no matter how strongly they may be implicated in the commercial side of a project and the ensuing dispute.

The problem with non-signatories in international commercial arbitration is not new. One of the first awards dealing with non-signatories goes back in the 1970 s, ${ }^{4}$ while the seminal article of Professor Ibrahim Fadlallah discussing nonsignatories in the context of corporate groups was published in 1987.5 Since then, arbitration doctrine and practice has attempted to respond to the nonsignatory challenge with a wide range of theories and legal constructs. Over the course of the last thirty years, non-signatories have been allowed or compelled to arbitrate on the basis of disparate doctrines such as agency and apparent authority, assignment, estoppel, alter ego and lifting the corporate veil, thirdparty beneficiary, incorporation by reference and not least the controversial doctrine of 'group of companies'.

As is generally accepted, most non-signatory theories are premised on the idea of implied consent, namely the idea that a non-signatory can be bound by an arbitration agreement, which it never signed, if it is found to have implicitly consented to it by conduct. 6

This article challenges the theoretical coherence and practical propriety of the non-signatory theories based on consent. More fundamentally, the article questions whether the traditional concept of consent for arbitration can be reconciled with complex commercial reality and the role of non-signatories today. As is shown, while the existing non-signatory theories can work well in straightforward circumstances, they are often unable to accommodate complex multiparty transactions that invariably involve non-signatories, in particular transactions with corporate groups and state entities. As is argued, this owes much to the fact that arbitration law on non-signatories has developed as a fragmented body of a wide number of disparate doctrines, which do not account for a general theory of non-signatories in arbitration.

\footnotetext{
4 See ICC case no 2138 of 1974, in Y Derains and S Jarvin (eds), ICC Arbitral Awards 1974-85 (Kluwer, 1990), 934; see also ICC case no 1434 of 1975, in Y Derains and S Jarvin (eds), ICC Arbitral Awards 1974-85 (Kluwer, 1990), 263.

5 I Fadlallah, 'Clause d'arbitrage et groupes de sociétés' (1987) Travaux du Comité Français de Droit International Privé 1984-1985 105.

${ }^{6}$ See B Hanotiau, Complex Arbitrations: Multiparty, Multicontract, Multi-issue, and Class Actions (Kluwer, 2003). E Silva Romero \& L M Velarde Saffer, "The Extension of the Arbitral Agreement to Non-Signatories in Europe: a Uniform Approach?" 5 Am. U. Bus. L. Rev. 2015-2016, 372.
} 
The article submits that a unifying theory for non-signatories is needed and goes on to propose that, under such theory, the theoretical basis for finding that non-signatories have rights or obligations in an arbitration should be shifted from the concept of consent to the concept of dispute. Under the proposed theory, what matters is not whether a non-signatory can demonstrate consent for arbitration, but whether it is inextricably implicated in a dispute which is the subject matter of an arbitration.

The article proceeds as follows. After a brief discussion of the most important non-signatory theories in Section II, Section III offers a critique of these theories. As is demonstrated, there is a clear divide between rhetoric and actual practice in respect of non-signatories in international commercial arbitration. While courts and tribunals insist that whether a non-signatory is bound by an arbitration agreement is a matter of consent, in reality the nonsignatory theories they apply are often alien to fundamental principles of consent. Section III goes on to argue that arbitration law on non-signatories is often unable to accommodate complex commercial reality, because in essence it is a body of fragmented theories that have been largely borrowed from national contract laws rather than developed for the distinct purposes of international arbitration. Finally, Section IV sets out the fundamental elements of a new unifying theory on non-signatories based on the concept of dispute.

\section{THE EVOLUTION OF ARBITRATION LAW ON NON-SIGNATORIES}

\section{A. Non-signatories and Ordinary Doctrines of Contract and Company Law}

Traditionally, arbitration has been used for the resolution of disputes arising out of bilateral transactions, mainly sales of goods and transport contracts. However, with the collapse of the non-arbitrability doctrine in the past forty years, ${ }^{7}$ and the policy of a large number of national laws favouring international arbitration, the scope of arbitration has greatly expanded. Currently, arbitration clauses are found in almost all forms of commercial contracts, including complex and multiparty projects.

However, its expansion to multiparty transactions has exposed the inherent limitations of arbitration which was traditionally conceived and developed as a bilateral dispute resolution system. Importantly, questions have been raised as to how non-signatory parties could be granted some ability to intervene or be joined in an arbitration deciding on a dispute which implicated them. ${ }^{8}$

\footnotetext{
7 The non-arbitrability doctrine refers to the body of rules whereby certain types of arbitration disputes, such as tax and insolvency disputes or other disputes associated with public policy, cannot be submitted to arbitration. See more in K. Youssef, 'The Death of Inarbitrability' in L. Mistelis and S. Brekoulakis (eds), Arbitrability: International and Comparative Perspectives (Alphen aan den Rijn: Kluwer, 2009) 47. See generally, Mistelis and Brekoulakis (eds), ibid.

8 S. I. Strong, "Intervention and Joinder as of Right in International Arbitration: an Infringement of Individual Contract Rights or a Proper Equitable Measure?" 31 VandJ Transnatl La 915 at 920.
} 
Arbitration's response to non-signatories has been, intuitively, to rely on its contractual instincts. National courts and arbitration tribunals have been treating parties who fail to sign an arbitration agreement as they treat parties who fail to sign an ordinary contract, namely by relying on well-known doctrines of contract law that purport to extend the contractual boundaries to third parties. Thus, a wide range of contract law doctrines dealing with third parties, such as agency and representation, assignment, incorporation by reference and third-party beneficiary have been employed by national courts and arbitration tribunals to deal with non-signatories in arbitration too.

The idea here is simple, if unsophisticated. If the underlying contract can extend to a non-signatory pursuant to a contract law doctrine, the arbitration clause in that contract should be able to extend to the non-signatory too. For example, a wide number of jurisdictions, including Austria, ${ }^{9}$ England, ${ }^{10}$ France, ${ }^{11}$ Germany, ${ }^{12}$ Switzerland ${ }^{13}$ and the US $^{14}$ accept the idea that when a claim or a contract is transferred to a third party by way of assignment, the arbitration clause contained in that contract will be transferred to that party too.

Similarly, under most national laws, when two parties agree to grant the substantive benefit of their contract to a third party, the third party beneficiary may benefit from the arbitration clause in that contract too. ${ }^{15}$ Likewise, it is generally accepted that when an agent possesses actual authority and power to sign an arbitration agreement in the name and on behalf of the principal, the non-signatory principal will be bound by the arbitration agreement. ${ }^{16}$ General principles of agency law also come into play when a non-signatory, typically a State, attempts to rely on idiosyncratic formalities of its national law to deny that it has validly authorised a state entity to sign an arbitration agreement on its behalf. In these circumstances, tribunals have applied the legal doctrine of apparent or ostensible authority to compel the non-signatory State to arbitrate, especially if the State has given the reasonable impression that the state entity was generally acting on behalf of the State. ${ }^{17}$

\footnotetext{
${ }^{9}$ OGH 13 June 1995, 4 Ob 533/95, SZ 68/112.

10 E.g. Montedipe v JTP-Ro Jugotanker (The Jordan Nicolov) [1990] 2 Lloyd's Rep 11.

${ }^{11}$ CA Paris, CCC Filmkunst v EDIF 28 January 1988, (1988) Rev Arb 565.

1212 November 1990-Bundesgerichtshof (Federal Supreme Court), in A-J van den Berg (ed), Yearbook of Commercial Arbitration xvii (Kluwer 1992) 510-12.

13 E.g. Switzerland Swiss Federal Tribunal, 9 May 2001, (2002) 20 ASA Bull 80.

${ }^{14}$ E.g. Asset Allocation and Management v Western Employer 892 F 2d 566 (7th Cir 1989).

15 E.g. Nisshin Shipping Co Ltd v Cleaves \& Co Ltd [2003] EWHC 2602 (Comm) and more recently Fortress Value Recovery Fund I LLC \& Ors v. Blue Skye Special Opportunities Fund LP \& Ors [2013] EWCA Civ 367. Cf also UK Contracts (Rights of Third Parties) Act 1999, s 8 provides that where a party conferred to a third-party beneficiary is subject to a valid arbitration clause, the third party shall be treated as a party to that arbitration clause as regards disputes between the third party and the promisor For France, see Cour de Cassation 11 July 2006, (2006) Rev Arb 969, with note C Larroumet.

16 For England, see Capital Trust Inv Ltd v Radio Design TJ AB [2002] EWCA Civ 135 (English Court of Appeal); for the US, see for example Westmoreland v Sadoux, 299 F 3d 462 (5th Cir 2002). For France, see Cass 2e civ, 14 October 1987, Ampafrance v Wasteels (1988) Rev Arb 288, with note J-L Goutal.

${ }^{17}$ See for example ICC Partial Award on Jurisdiction and Admissibility in case no. 6474 of 1992 in A-J van den Berg (ed), Yearbook of Commercial Arbitration, XXV (Kluwer Law International, 2000) 279-311.
} 
On other occasions, national courts, mostly in the US, have relied on principles of estoppel to compel a non-signatory to arbitrate when the latter seeks to enforce substantive rights under a contract that contains an arbitration clause. ${ }^{18}$ When, for example, a non-signatory buyer brings a claim directly against the manufacturer relying on warranty provisions in the contract between the manufacturer and the distributor, the non-signatory buyer may be estopped from denying the arbitration clause in the contract between the manufacturer and the distributor. ${ }^{19}$

Finally, the doctrine of lifting the corporate veil, which was originally developed in company law to prevent abuse of the legal principle of limited liability, ${ }^{20}$ has been used to deal with non-signatories in arbitration too. Some national courts and arbitration tribunals, albeit in exceptional only circumstances, have lifted the corporate veil of the signatory subsidiary to find that the non-signatory parent company is the true party to an arbitration agreement, especially if the subsidiary is insolvent at the time a dispute arises or lacks sufficient funds to cover the damages requested by the claimant. ${ }^{21}$

\section{B. The 'Group of Companies' Doctrine}

In addition to contract and company law doctrines, a number of arbitration scholars in the 1990s explored theoretical options to extend third-party mechanisms, such as joinder and consolidation, available in national litigation to international arbitration. ${ }^{22}$ While the debate about joinder and consolidation highlighted some important analytical links between the ability of third parties to participate in a litigation which implicates them and the need of nonsignatories to be able to do the same in arbitration, it never had any appeal in the practice of international arbitration.

Instead, a number of arbitration tribunals in the 1980s and 1990s relied on the doctrine of group of companies to assume jurisdiction over non-signatories in disputes involving corporate groups. Although some awards had held that an arbitration agreement could be extended to non-signatory members of a corporate group since the $1970 \mathrm{~s}^{23}$ the 'group of companies' idea was first articulated by the celebrated Dow Chemical $v$ Isover-Saint-Gobain award in the early 1980 s. $^{24}$ Two subsidiaries of the Dow Chemical Company group entered into two separate distribution agreements with Boussois-Isolation, whose rights

\footnotetext{
18 By way of example, see Deloitte Noraudit A/S v Deloitte Haskins \& Sells 9F 3d 1060 (2d Cir 1993).

${ }^{19}$ International Paper v Schwabedissen Maschinen \& Anlagen Gmbh 206 F 3d 411 (4th Cir 2000).

${ }^{20} \mathrm{P}$ Blumberg, The Law of Corporate Groups: Tort, Contract, and Other Common Law Problems in the Substantive Law of Parent and Subsidiary Corporations (Little Brown 1989) 105-6.

21 See, for example, Ad hoc award of 1991, (1992) 2 ASA Bull 202.

22 B Hanotiau, Complex Arbitrations: Multiparty, Multicontract, Multi-issue, and Class Actions (Kluwer 2003)

${ }^{23}$ See for example ICC case no 2138 of 1974, in Y Derains and S Jarvin (eds), ICC Arbitral Awards 1974-85 (Kluwer, 1990).

${ }^{24}$ Interim Award of 23 September 1982, ICC Case No. 4131, Y.C.A. Vol. IX (1984), 131 and Clunet 1983 , at 899 et seq.
} 
and obligations were subsequently assigned to Isover-Saint-Gobain. When a dispute arose out of the distribution agreements, which contained a provision for arbitration under the rules of the International Chamber of Commerce (ICC), the two Dow Chemical subsidiaries together with the non-signatory parent company (Dow Chemical USA) and another non-signatory subsidiary (Dow Chemical France) initiated arbitration proceedings against Isover-Saint-Gobain in France. The respondent argued that the tribunal lacked jurisdiction over the nonsignatory parties (l'exception d'incompétence), and that the non-signatory claims were non-admissible (l'exception d'irrecevabilité).

The tribunal applied substantive rules of international commerce, which according to the tribunal- included the 'group of companies' doctrine, and found that it had jurisdiction not only over the two signatories but also over the two non-signatory companies of the Dow Chemical group on the basis that first, all claimants, including the non-signatories, were companies of the same group; second, the non-signatory companies had assumed an active role in the conclusion, performance and termination of the distribution agreements, which contained an arbitration clause; third, the factual circumstances of the case demonstrated common intention for arbitration between the claimants, including the non-signatories, and the respondents.

The Dow Chemical award marked a genuine moment of progress in the law of international arbitration, which came about because of the fortunate coincidence of two circumstances: first, the reformist Nouveau Code of Procédure Civile of 1981 that had introduced a progressive arbitration law in France, namely the seat of the Dow Chemical arbitration.

Second, the fact that the Dow Chemical dispute was decided by a 'strong' arbitration tribunal with intellectual confidence and distinct international outlook. Professor Pieter Sanders, who was chairing the Dow Chemical tribunal, and Professor Berthold Goldman who was sitting as a co-arbitrator were stalwarts of international law and international arbitration. Professor Sanders was a Dutch lawyer who had almost singlehandedly drafted the 1976 UNCITRAL Arbitration Rules and the 1958 United Nations Convention on the Recognition and Enforcement of Foreign Arbitral Awards, which went on to become one of the most successful international treaties and the cornerstone of modern international arbitration practice. Professor Goldman was a French comparativist who was behind a number of progressive developments in international law, such as the concept of international companies (société internationale) and the revival of lex mercatoria and transnational substantive rules in the 1960s. Having a unique appreciation of the international settings of arbitration and a strong belief in the reformist power of international law, the Dow Chemical tribunal was able to conceptualize arbitration agreements in international business transactions as autonomous and independent of the main contract, and subject only to transnational legal rules. Liberated from the constraints of national laws, an arbitration agreement was thus able to bind a 
non-signatory party, especially if this party was implicated in the performance of the underlying contract. In the words of the Dow Chemical award: ${ }^{25}$

Considering, in particular, that the arbitration clause expressly accepted by certain of the companies of the group should bind the other companies which, by virtue of their role in the conclusion, performance, or termination of the contracts containing said clauses, and in accordance with the mutual intention of all parties to the proceedings, appear to have been veritable parties to these contracts or to have been principally concerned by them and the disputes to which they may give rise. [emphasis added]

In one of the most progressive legal reasoning in international commercial arbitration, the Dow Chemical tribunal went on to emphasise that international arbitration should elaborate rules to respond to 'economic reality' and the 'needs of international commerce': 26

Considering that irrespective of the distinct juridical identity of each of its members, a group of companies constitutes one and the same economic reality (une réalité économique unique) of which the arbitral tribunal should take account when it rules on its own jurisdiction [...]

Considering that ICC arbitral tribunals have already pronounced themselves to this effect. The decisions of these tribunals progressively create caselaw which should be taken into account, because it draws conclusions from economic reality and conforms to the needs of international commerce, to which rules specific to international arbitration, themselves successively elaborated should respond. [emphasis added]

Although the respondent, predictably, applied to the French courts to set the award aside, the Paris Cour d'appel upheld the award and confirmed jurisdiction of the tribunal over the non-signatory Dow Chemical companies. ${ }^{27}$

Since the Dow Chemical award a number of tribunals applied the 'group of companies' doctrine to assume jurisdiction over non-signatories. ${ }^{28}$ Nevertheless, the doctrine never actually found broad acceptance in international arbitration. Almost every arbitral award that relied on the 'group of companies' doctrine was issued by a tribunal sitting in France and deciding under the ICC Arbitration Rules. Arbitration tribunals and national courts outside France, especially in common law jurisdictions, never accepted the idea that separate legal entities can be treated as an corporate group, ${ }^{29}$ whether for substantive or jurisdictional purposes, and remained strictly adherent to the fundamental, if artificial, principle of separate legal personality and limited liability.

\footnotetext{
25 Interim Award of 23 September 1982, ICC case No. 4131, above (note 24).

26 Ibid.

27 Paris Cour d'Appel, 21 October 1983, (1984) Rev Arb 98 with note Chapelle.

${ }^{28}$ ICC Case no 5103 of 1988, (1991) 2(2) ICC Bull 20; ICC Case no 6519 of 1991, J Arnaldez, Y Derains, and D Hascher (eds), ICC Collection of Arbitral Awards 1986-1990 (Kluwer, 1997) 420.

${ }^{29}$ See, for example, the landmark decision of the UK House of Lords in Salomon $v$ Salomon [1896] UKHL 1.
} 


\section{THE PROBLEM WITH THE EXISTING NON-SIGNATORY THEORIES}

Despite the existence of such a wide range of non-signatory theories, the arguments about non-signatories persist and pervade the debates surrounding international arbitration. While the number of disputes involving nonsignatories has constantly increased in the last thirty years, ${ }^{30}$ commentators have observed that the 'existing jurisprudence [on non-signatories] requires substantial doctrinal development'. 31

More worrisome, while a number of arbitral institutions have amended their rules in order to allow the participation of non-signatory in the arbitration, ${ }^{32}$ an increasing number of awards dealing with non-signatories has been either set aside or refused enforcement by national courts. ${ }^{33}$ Thirty years after the Dow Chemical award, international arbitration seems to still be struggling to develop rules that may respond to 'the needs of international commerce', at least, with respect to non-signatories.

There are three main problems with the existing non-signatory theories. First, the way courts and tribunals deal with non-signatories reveals a confusing divide between rhetoric and actual practice, which essentially contravenes fundamental principles of consent. Secondly, arbitration law on non-signatories is often unable to accommodate complex commercial reality. Thirdly, the existing non-signatory theories have been largely borrowed from contract national laws rather than been specifically developed for international arbitration.

These three issues and their implications for both arbitration theory and arbitration practice are examined in turn.

\section{A. The Divide Between Rhetoric and Actual Practice with Respect to Non- signatories in International Commercial Arbitration}

The existing theories on non-signatories are premised on the idea of implicit consent, namely the idea that a non-signatory can be bound by an arbitration agreement, if it has implicitly consented to it by conduct. National court decisions and international arbitral awards abound by commonplace, if banal, ${ }^{34}$

\footnotetext{
${ }^{30}$ For example, while only one out of five International Chamber of Commerce (ICC) arbitrations involved more than two parties in 1989 (International Court of Arbitration Bulletin, (Volume 1, Number 1), (1990), p. 8) in 2014 one out of three ICC arbitrations involved more than two parties (see ICC Dispute Resolution Bulletin, (Issue 1, 2015), p. 8).

${ }^{31}$ Martinez- Fraga, above (note 1) at 294.

32 E.g., Articles 7-10 of the 2011 Arbitration Rules of ICC, Rule 24(1)(b) of the 2013 Arbitration Rules of the Singapore International Arbitration Centre and Articles 7 and 8 of the 2014 Arbitration Rules of the International Centre for Dispute Resolution.

${ }^{33}$ See for example, the decisions of the English Supreme Court in Dallah $v$ Government of Pakistan, [2010] UKSC 46, and the decision of the English High Court in Peterson Farms Inc v C\&M Farming Ltd [2004] 1 Lloyd's Rep 603, the decision of the Court of Singapore in PT First Media TBK $v$ Astro Nusantara International BV and others [2013] SGCA 57, the decision of the Swiss Federal Tribunal, Decision 4A_450/2013 on 7 April 2014.

34 As Alan Rau aptly observes in 'Arbitral Jurisdiction and the Dimensions of "consent"' (2008) 24 Arbitration International 199.
} 
propositions to the effect that 'arbitration is a matter of contract and a party cannot be required to submit to arbitration any dispute which he has not agreed so to submit'. ${ }^{35}$

Even the 'group of companies' doctrine, which originally arrived as a progressive theory aiming to reconcile international arbitration with economic reality and the needs of international commerce, never actually departed from the idea of consent. Almost every arbitration award relying on the 'ground of companies' doctrine has emphasised the need that signatories and nonsignatories exhibit 'common intention' to arbitrate. ${ }^{36}$

However, while national courts and arbitration tribunals insist that whether a non-signatory is bound by an arbitration agreement is a matter of consent, in reality, consent for arbitration is often lacking in the non-signatory theories they apply. Specifically, we can distinguish between two groups of non-signatory theories. In the first, non-signatories may be allowed or compelled to arbitrate on the basis of equity, not consent for arbitration. In the second, non-signatories may be allowed or compelled to arbitrate on the basis of a functional concept of consent that concerns the underlying substantive contract, not the arbitration agreement. In either group, it is questionable whether consent for arbitration actually exists.

The first group includes the doctrines of apparent or ostensible authority, alter ego, lifting the corporate veil and estoppel. Each one of these doctrines is based on equitable considerations. The doctrine of ostensible authority, for example, is premised on the general principle of prohibition of abuse of rights, ${ }^{37}$ recognised in both common and civil law jurisdictions. ${ }^{38}$ Similarly, the doctrine of arbitral estoppel reflects the general principle of non-venire contra factum proprium, found in many contemporary civil law jurisdictions and originally in Roman law. ${ }^{39}$

Under these doctrines, the non-signatory party is compelled to arbitrate not because it has actually agreed to arbitrate, but because it would be unfair if it were allowed to escape arbitration. It would be unfair, for example, if a State were allowed to escape arbitration in circumstances where it has lead a party to reasonably believe that a state entity was acting with authority to conclude an arbitration clause, even if such authority is actually missing. Equally, it would be

\footnotetext{
35 United Steelworkers of America v. Warrior \& Gulf Nav. Co., 363 U.S. 574, 582 (1960).

${ }^{36}$ See for example, the arbitral award in ICC case no 4131 of 1982, Dow Chemical v Isover-SaintGobain (1984) 9 YBCA 131; ICC case no 6000 of 1988, (1991) 2(2) ICC Bull 34; ICC award, on 10 March 2003, C\&M Farming Ltd v Peterson Farms Inc (unpublished).

${ }^{37}$ Cf G Born, International Commercial Arbitration, (Kluwer, 2014) 1425.

${ }^{38}$ In England see R Munday, On Agency (Oxford University Press, 2010) ch 4; in France the rule has been established since the 19th century in the case of the Cour de Cassation, 16 January 1861, Lizardi $v$ Chaize, Sirey, Pt I, at 305 (1861); in the US see Restatement (Third) Agency para 2.03 (2006). Cf also UNIDROIT Principles of International Commercial Contracts Art 2.2.5(2) (2004).

${ }^{39} \mathrm{E}$ Gaillard, 'L'Interdiction de se contredire au détriment d'autrui comme principe général au droit du commerce international' (1985) Rev Arb 241; See also Born, above (note 37) p. 1471; T Zuberbühler, 'Non-Signatories and the Consensus to Arbitrate' (2008) 26(1) ASA Bull 30.
} 
unfair if a party, which seeks to enforce a substantive right under a contract that contains an arbitration clause, were allowed to cherry-pick and enjoy the substantive benefit of the contract, while denying the arbitration clause therein. Finally, it would be unfair if an individual or a parent company were allowed to escape arbitration, by hiding behind the corporate veil of a wholly owned subsidiary to frustrate the interests of a claimant in an arbitration.

Recently, the Swiss Federal Tribunal even relied on the principle of good faith to compel a non-signatory party to arbitrate. ${ }^{40}$ In this case, an arbitral tribunal sitting in Switzerland had denied jurisdiction over a non-signatory parent company, although the latter was involved in a contract that contained an arbitration clause, singed by its subsidiary. Setting aside the arbitral award, the Swiss Federal Tribunal noted that when a non-signatory acts in such a manner that leads someone to believe that it is a true party to a contract, the principle of good faith requires that the non-signatory party be bound by the arbitration clause included in that contract.

Under all these doctrines, including the principle of good faith, arbitration tribunals and national courts have compelled non-signatories to arbitrate because of fundamental considerations of equity, not consent for arbitration. Arbitrators and arbitration practitioners are typically struck with horror whenever the question of equity arises in arbitration. Equity tends to conflict with our hard-wired positivistic instincts, and arbitrators are habitually reluctant to consider equitable arguments lest they are perceived to act as amiable compositeurs or engaging in administration of justice. ${ }^{41}$

Nonetheless, the main idea underlying all these non-signatory theories is equity, not consent for arbitration. As the Tribunal in the Westland case acknowledged in deciding to accept jurisdiction over a number of non-signatory States:

[M] ention must be made of the practical reasons and considerations of equity which have motivated the arbitrators in this matter, quite apart from the legal ground. Westland is justified in bringing the four States themselves before the arbitrators. Were this not the case, there would be a real denial of justice. In other words, Westland would not recover anything. ${ }^{42}$

The second group includes the doctrines of assignment, third-party beneficiary and implied consent including the 'group of companies' doctrine. These doctrines are premised on a notion of constructive consent that aims at the underlying substantive contract, not the arbitration agreement. While a form of consent exists in these cases, it is not consent for arbitration.

\footnotetext{
${ }^{40}$ Swiss Federal Tribunal, Decision 4A_450/2013 dated 7 April 2014. See also older decision of the Swiss Federal Tribunal in Compagnie de Navigation et Transp. SA v. Mediterranean Shipping Co., XXI Y.B. Comm. Arb. 690, 698, 16 January 1995.

41 Bernard Hanotiau, 'Consent to Arbitration: Do We Share a Common Vision?' (2011) Arbitration International (4)27, 541.

42 ICC interim award of 5 March 1984 in case No 3879, 11 Y.B. Com. Arb. 127 (1986).
} 
For example, in most jurisdictions it is accepted that a third party beneficiary who enjoys the benefit of a substantive clause in a contract, may also benefit from the arbitration clause in that contract, even if the original parties did not specifically agree to pass on the benefit of the arbitration clause to the third party..$^{43}$ Proof that the original parties agreed to provide a third party with a substantive benefit generally suffices for the beneficiary to enforce its substantive benefit through arbitration. Similarly, the rule that an arbitration agreement is automatically transferred when the underlying contract is assigned does not require proof that the assignee has specifically consented for the assignment of the arbitration clause. Consent for the assignment of the substantive right is typically sufficient for the assignee to bring a claim in arbitration. ${ }^{44}$

Further, in applying the 'group of companies' doctrine, arbitration tribunals often rely on circumstances surrounding the underlying substantive contract or transaction (not the arbitration agreement) to infer consent for arbitration. On several occasions, arbitration tribunals have found that an active involvement of a non-signatory company in the performance of the underlying contract can be taken as evidence of consent for arbitration. ${ }^{45}$ In these cases, it is the nonsignatory's acquiescence to deliver goods or perform part of the substantive contract, rather than the non-signatory's implied consent for arbitration, that has empowered tribunals to accept the non-signatory in arbitration. ${ }^{46}$

This broad concept of constructive consent, used by national courts and arbitration tribunals as a proxy of consent for arbitration, rests upon the assumption that an arbitration agreement which already exists requires 'less consent' or at least 'less evidence of consent' to bind a non-signatory than the original signatories. ${ }^{47}$ This is why it is generally accepted that, while consent for arbitration must be evidenced in writing when two signatories first enter into an arbitration agreement, proof of consent in writing is not needed for nonsignatories that are subsequently added to an existing arbitration agreement. ${ }^{48}$

French courts have taken the argument for diminished arbitration consent a step further and have found that even mere awareness of the existence of an arbitration clause in an international contract may be sufficient for a non-

\footnotetext{
43 See above (note 15 ).

${ }^{44}$ See above (notes 9-14).

${ }^{45}$ See for example, ICC case no 5103 of 1988 (1991) 2(2) ICC Bull 20 Soci.t. Sponsor AB v Lestrade (Cour d'Appel Paris (1988) Rev Arb 154, with note A Chapelle). See also the Dow Chemical award, above (note 24), and ICC case no 6000 of 1988, (1991) 2(2) ICC Bull 32.

46 See Hanotiau above (note 41), p. 539 'this type of analysis is wrongly used as a shortcut to avoid legal reasoning and as such has contributed to a distorted approach by courts and arbitrators in a number of complex arbitrations' and Born, above (note 37), p. 1429.

47 This is especially the case when tribunals and courts are examining whether a signatory has consented to arbitrate with a non-signatory. See Rau, above (note 34).

${ }^{48}$ See the passage often cited in US cases in Fisser v International Bank $282 \mathrm{~F} 2 \mathrm{~d}$ 231, 233 (2d Cir 1960): 'It does not follow, however, that under the [Federal Arbitration] Act an obligation to arbitrate attaches only to one who has personally signed the written arbitration provision.'
} 
signatory party to be compelled to arbitrate. For example, the Cour d'Appel of Paris in Korsnas Marma v Durand-Auzias noted:

[A]n arbitration clause included in an international contract has an autonomous validity and effectiveness, which calls for the clause to be extended to parties directly involved in the performance of the contract and in the disputes arising out of the contract, provided that it is established that their activities raise the presumption that they were aware of the existence and the scope of the arbitration clause, irrespective of the fact that they did not sign the contract including the arbitration agreement. ${ }^{49}$ (emphasis added)

It must be questioned whether this approach to arbitration agreements is reconciled with fundamental principles of consent. An arbitration agreement cannot bind a third party merely because it exists between two other parties, or merely because a third party is aware of its existence.$^{50}$ Fundamental principles of contract law entail that the same amount of consent and evidence of consent are required for a non-signatory to be bound by an arbitration agreement as by any ordinary contract. ${ }^{51}$ Consent for arbitration is a matter of kind not degree, and there is no national arbitration law or arbitration treaty providing that arbitration clauses require less consent or less evidence of consent.

In essence, in cases involving non-signatories, national courts and arbitration tribunals have realised that in commercial reality it is not always possible for businesspeople to consent to every term of a transaction, including an arbitration clause. This realisation has forced them to develop legal fictions that have expanded the scope of consent for arbitration far beyond what the parties ever had in mind. However, the use of proxies (such as the fact that a non-signatory participates in the main contract or that it is aware of the existence of an arbitration agreement) to 'demonstrate' consent for arbitration runs afoul with the very idea of consent, as a conscious and informed decision of an individual to abide by an unequivocal promise. ${ }^{52}$

It becomes apparent thus that a clear divide between rhetoric and actual practice exists in respect of non-signatories in international commercial

\footnotetext{
${ }^{49}$ Cour d'Appel, Paris, 30 November 1988, Korsnas Marma v Durand-Auzias, (1989) Rev Arb 691, at 694 with note P-Y Tschanz; Cour d'Appel, Paris, 11 January 1990, Orri v Lubrifiants Elf Aquitaine, (1992) Rev Arb 95, with note D Cohen; (1991) 118 JDI 141, with note B Audit; Cour de Cassation, 27 March 2007, Alcatel Business Systems, Alcatel Micro Electronics and AGF v Amkor Technology et al, Cass 1e civ, [2007] 11 JCP I 168, with note C Seraglini.

50 See D Cohen, note in Cour de Cassation, 5 January 1999, and Cour de Cassation, 19 October 1999, (2000) Rev Arb 92, noting that 'the validity of a contract does not entail the extension of this contract, and, thus, arbitration agreements cannot contravene the general principles of contract law in this regard'. Cf also Thomson-CSF v American Arbitration Ass'n 64 F 3d 773 (2d Cir 1995) 779, at 780.

51 See Williston on Contracts, (4th edn WestGroup, 2001) para 57:1.

52 Cf Richard Frankel "The Arbitration Clause As Super Contract”, 91 Wash. U. L. Rev. 2013-2014, 531, arguing that "the judiciary's inappropriate reliance on the federal policy favoring arbitration distorts state contract law to push cases into arbitration that do not belong there".
} 
arbitration. ${ }^{53}$ Whereas in theory national courts and tribunals defend the extension of arbitration agreements to non-signatories on consensual grounds, in reality the non-signatory theories they apply are alien to fundamental principles of consent. Indeed, the concept of consent for arbitration, employed by national courts and tribunals, is markedly different from the concept of consent normally used for ordinary contracts. ${ }^{54}$ While it is possible that this divide is the result of a genuine misunderstanding of contract law, it is likely that it is the result of a general policy favouring the enforcement of international arbitration agreements. ${ }^{55}$ While such a pro-arbitration policy may be sound, its consensual justifications are often indefensible.

In all events, this divide has been spectacularly exposed in a number of cases, including the well-known Dallah $v$ Government of Pakistan, where the UK Supreme Court and the French Court of Appeal in Paris, two very prominent national judiciaries, reached diametrically opposing decisions on the issue of implied consent and non-signatories.

In this case, the Government of Pakistan entered into a Memorandum of Understanding with Dallah, a Saudi Arabian construction company, to provide housing in Saudi Arabia for Pakistani pilgrims to Mecca. Following a period of negotiations between Dallah and Pakistani Government ministers, the Government of Pakistan set up a Trust to enter into an agreement with Dallah (the 'Agreement'). The Agreement contained the terms (including an ICC arbitration clause for Paris) that were previously negotiated by the Government. Although it was not a signatory to either the Agreement or the arbitration clause, the Government of Pakistan, including certain members of it, became actively implicated in the performance and management of the construction project. When a dispute arose out of the Agreement, the Trust ceased to exist. Faced with the rather unappealing prospect of bringing a claim against the Government of Pakistan before the Pakistani Courts, Dallah decided to commence arbitration proceedings in Paris against the non-signatory Government. While the tribunal, sitting in Paris, accepted jurisdiction over the Government, the UK Supreme Court refused to enforce the award on the grounds that the Government was not a party to either the Agreement or the arbitration clause.

The UK Supreme Court was rather unimpressed by the tribunal's decision that the non-signatory Government of Pakistan had implicitly consented to arbitration on the basis that it was a party to the Memorandum of Understanding

\footnotetext{
53 Lawrence Cunningham, 'Rhetoric Versus Reality in Arbitration Jurisprudence: How the Supreme Court Flaunts and Flunks Contracts', (2012) 129 Law and Contemporary Problems 135. ${ }^{54}$ See in more detail Frankel, above (note 52).

55 E.g. US Supreme Court decision in Moses H. Cone Memorial Hospital v. Mercury Construction Corp., 460 U.S. 1 (1983): 'it is a congressional declaration of a liberal federal policy favoring arbitration agreements, notwithstanding any state ... policies to the contrary' and Mitsubishi Motors Corp. v. Soler Chrysler-Plymouth, Inc., 473 U.S. 614, 631 (1985) holding that the in the context of international commercial transactions there is a "emphatic federal policy" favouring arbitration. See also in England Westacre Investments Inc. v. Jugoimport-Spdr Holding co. Ltd. and others, [2000] Q.B. 288 at 304. See also Aubrey Thomas, "Non-Signatories in Arbitration: a Good Faith Analysis" 14 Lewis \& Clark L. Rev. 2010, 953.
} 
and was implicated in the performance of the Agreement, including providing a guarantee in favour of the Trust. Lord Collins noted:

There was no material sufficient to justify the tribunal's conclusion that the Government's behaviour showed and proved that the Government had always been [...] a true party to the Agreement and therefore to the arbitration agreement. On the contrary, [...] on the face of the Agreement the parties and the signatories were Dallah and the Trust. The arbitration clause related to disputes between the Trust and Dallah. 56

By contrast, the French Court of Appeal, which issued its decision only a few months after the decision of the UK Supreme Court, found that the factual circumstances surrounding the Agreement provided comprehensive evidence that may be relied upon to conclude that the Government of Pakistan was the true party to the Agreement and the arbitration clause therein. The French court noted:

[The Government] behaved as if the Contract was its own; [...] this involvement of [the Government], in the absence of evidence that the Trust took any actions, as well as [the Government's] behaviour during the pre-contractual negotiations, confirm that the creation of the Trust was purely formal and that [the Government] was in fact the true Pakistani party in the course of the economic transaction. ${ }^{57}$ (emphasis added)

It is reassuring to think that the two distinguished courts had merely different views on the facts of the case. ${ }^{58}$ The truth of the matter is that the conflicting decisions in the Dallah case highlights two more fundamental issues in international commercial arbitration: first, the deficiencies of the allencompassing concept of constructive consent currently used for arbitration agreements. Second, the lack of a coherent approach to non-signatories under the existing theories.

\section{B. The Existing Non-signatory Theories are Often Unable to Accommodate Complex Commercial Reality}

In addition to being incoherent and partly in conflict with fundamental principles of consent, the current approach to non-signatories exhibits important practical deficiencies. While the existing non-signatory theories can work well in straightforward circumstances, they are often unable to offer solutions in more sophisticated cases of multiparty transactions, such as in transactions with multinational groups and state entities.

\footnotetext{
56 Lord Collins in Dallah v Government of Pakistan, [2010] UKSC 46, para 145.

57 See decision of 17 February 2011, in Gouvernement du Pakistan - Ministère des Affaires Religieuses v. Dallah Real Estate and Tourism Holding Company (Case No. 09/28533).

58 Cf also Arsanovia Ltd. \& Ors v. Cruz City I Mauritius Holdings [2012] EWHC

(Comm) 3702, [35] holding that "English law requires that an intention to enter into an arbitration clause must be clearly shown and is not readily inferred".
} 
It is common practice, for example, for a State or a parent company to set up a state entity or a subsidiary to sign a contract, including an arbitration clause, which the State and the parent company negotiate in the first place and subsequently manage from the background..$^{59}$ However, when the State or the parent company does not actually sign the contract and the arbitration clause, the existing non-signatory theories will often be unable to assist a claimant to bring the State or the parent company before a tribunal, irrespective of how strongly they may be implicated in the commercial side of the transaction.

Indeed, if the State or the parent company is careful enough (as they normally are) to avoid any explicit declaration of acceptance of transactions conducted by state entities or subsidiaries, there will be no formal authorization to engage principles of agency law. Any effort to bind the non-signatory State or the parent company to an arbitration agreement on the basis of representation will fail.

Equally, transactions with state entities and corporate groups will often fall outside the scope of provisions on third-party beneficiary and assignment law. A non-signatory State or a parent company will not normally qualify as a thirdparty beneficiary unless there is express wording to that effect, which will be normally missing. ${ }^{60}$ If there is no evidence that a state entity or a subsidiary and another party have agreed to assign or confer a substantive benefit of their contract to the State or the parent company, there will be no basis to argue that the latter can be compelled to arbitrate.

Similarly, while equitable doctrines, such the doctrines of apparent authority, good faith, alter ego and equitable estoppel, have to some extent advanced arbitration law beyond its contractual origins, they too exhibit clear conceptual and practical limitations. Being equitable in nature, their main function is to correct flagrant aberrations resulting from the strict application of legal constructs, such as the doctrine of limited liability or separate legal personality. ${ }^{61}$ As a result, these equitable doctrines are designed to apply in extraordinary circumstances, not in ordinary business transactions which nowadays tend to be multifaceted and multiparty.

For example, the doctrine of lifting the corporate veil has very rarely been accepted by national courts and arbitration tribunals and only on the basis of stringent requirements, such as that a parent company has fraudulently used the corporate structure with the purpose of avoiding liability and defeating the interests of the claimant. This type of circumstances is rare and difficult to prove in practice. ${ }^{62}$

Further, national courts and arbitration tribunals are characteristically reluctant to apply theories of apparent authority to compel a non-signatory to

\footnotetext{
59 P Blumberg, 'Limited Liability and Corporate Groups' (1986) 11 Journal of Corporate Law 574. 60 See Fortress Value Recovery Fund I LLC \& Ors v. Blue Skye Special Opportunities Fund LP \& Ors [2013] EWCA Civ 367.

61 Martinez Fraga, above (note 1), p. 314.

62 See Service Iron Foundry, Inc v MA Bell Co 588 P 2d 463, 473 (Kan Ct App 1978).
} 
arbitration. For example, in the Bridas $v$ Government of Turkmenistan, ${ }^{63}$ the US Fifth Circuit did not accept that the Government of Turkmenistan was bound as an apparent principal by an arbitration clause signed by Turkmenneft (an instrumentality formed and owned by the government of Turkmenistan). The Court found that while the government of Turkmenistan had made false representations to the effect that Turkmenneft was acting as its agent, it was not reasonable for Bridas to rely on such representations. The Court noted:

Had Bridas truly felt that Turkmenneft was signing the agreement not for itself but on behalf of the Government, it had the obligation to make that fact clear on the face of the agreement. This could have been accomplished in a myriad of ways. Bridas could have requested that the Government sign the agreement, or inserted a prominent and direct statement as to Turkmenneft's status.

Finally, despite its progressive character, or possibly because of it, the 'group of companies' doctrine has had a diminished relevance in arbitration practice since the 1990s. As already mentioned, very few arbitration tribunals, and certainly none outside France, have been willing to apply the doctrine lately, while a number of commentators have strongly opposed it. ${ }^{64}$

As a result, while international business transactions have increasingly become multifaceted, multiparty and multi-contract, international arbitration has been blissfully resting on a group of disparate non-signatory theories, with a narrow scope or stringer requirements of application. As a result, arbitration has often been unable to accommodate the realities of international contemporary commerce. Importantly, whenever an arbitration tribunal attempted to emphasise commercial practices at the expense of doctrine, it came to regret such attempt.

For example, in C\&M $v$ Peterson Farms, 65 the claimant commenced arbitration proceedings claiming damages suffered by the C\&M group of companies as a whole, including members of the group which had not signed the sales agreement and the arbitration clause therein. The arbitration tribunal sitting in London found that it had jurisdiction to deal with damages which were suffered not only by the signatory claimant (the C\&M parent company), but also the non-signatory C\&M companies. Although the arbitrators found that the nonsignatory C\&M companies were strongly implicated in the commercial side of the sales transaction, and that in reality the respondent had been dealing with C\&M as a group, the High Court of England set the award aside on the basis that the

\footnotetext{
${ }^{63}$ Bridas SAPIC, Bridas Energy International Ltd, Intercontinental Oil and Gas Ventures Ltd and Bridas Corporation v Government of Turkmenistan and State Concern Tukmenneft, 345 F.3d 347 (5th Cir 2003).

${ }^{64}$ Hanotiau, 'Consent to Arbitration', above (note 41), p. 546; Stephan Wilske, Laurence Shore \& Jan-Michael Ahrens 'The 'Group Of Companies Doctrine' - Where Is It Heading?' (2006) 17 American Review of International Arbitration 73.

65 ICC award, on 10 March 2003, C\&M Farming Ltd v Peterson Farms Inc (unpublished).
} 
non-signatory $\mathrm{C} \& \mathrm{M}$ companies had not actually signed the arbitration agreement in the main contract. ${ }^{66}$

Whilst the decision of the High Court is plausible and consistent with arbitration doctrine, it appears to be in tension with commercial practices concerning transactions with multinational groups. Adopting a corporate group structure can be an effective mode of corporate organisation and operation that allows multinationals to rationalise the division of tasks and labour within the group. If such a corporate structure makes good commercial sense, why should a parent company be unable to bring a claim in arbitration requesting damages suffered by the group as a whole?

Without a general theory that is the functional equivalent of the 'group of companies' doctrine, arbitration law is unable to address a wide number of multiparty transactions, especially relational transactions that run over a period of time, such as joint ventures, construction projects, franchises, concession contracts, financing agreements, licence agreements and long-term supply contracts. These relational agreements tend to develop in ways that often go beyond the four corners of the contract concluded at the very beginning of a long-term project. In this type of transactions, non-signatories, who for a number of commercial reasons are not part of the contract in the first place, often become involved in the actual project as this develops in time. If subsequent involvement of non-signatories in the commercial side of a project is disregarded for the purposes of arbitration (as many tribunals and national courts tend to do nowadays), ${ }^{67}$ international arbitration will become irrelevant to a wide number of complex relational transactions. ${ }^{68}$

\section{The Unwarranted Identification Between Contract and Arbitration Law}

To a large extent, the issues surrounding arbitration law on non-signatories reflect the challenges for contract law to respond to the inadequacies of classical contract law theories and move towards more relational norms not limited to implied consent or consent by conduct.

While in the $19^{\text {th }}$ century the primary paradigm of contract law was underpinned by consensual theories and was based on an exchange of promise, in the course of the $20^{\text {th }}$ century a number of theorists exposed the artificial formality of the promise-based idea of contract, and developed normative accounts that moderate the role of consent. ${ }^{69}$ Either because of relational

\footnotetext{
66 Peterson Farms Inc v C\&M Farming Ltd [2004] 1 Lloyd's Rep 603.

67 See for example, Award in ICC Case No. 6673, in J.-J. Arnaldez, Y. Derains \& D. Hascher (eds.), Collection of ICC Arbitral Awards 1991-1995 429 (1997); Award in Geneva Chamber of Commerce of 24 March 2000, 21 ASA Bull. 781 (2003).

68 As a result businesspersons may consider resorting to litigation for multiparty transactions especially national courts with reputation in the resolution of international commercial disputes such as the English High Court or the newly established Singapore International Commercial Court.

${ }^{69}$ See Luke Nottage, 'Tracing Trajectories in Contract Law Theory: Form in Anglo-New Zealand Law, Substance in Japan and the United States,' (2013) 4 (2) Yonsei Law Journal 175.
} 
theories, emphasising a wide range of contextual matters surrounding a contract, ${ }^{70}$ or because of theories focusing on benefit or reliance as the primary justification for contractual obligations and liabilities, ${ }^{71}$ contract law theory of the $20^{\text {th }}$ century conceptualised contractual paradigms that transcend consent.

It is important to note that post-consent theories of contract law developed to provide a more persuasive explanation than the classical and neoclassical theories on consent as to how contracts actually work in contemporary business transactions. ${ }^{72}$ For example, the notion of an instant exchange of promise between two commercial parties for future performance as a distinct obligation from the actual transaction became increasingly difficult to reconcile with the realities of long-term business relationships. ${ }^{73}$ Equally, the notion that an instant exchange of promises must be demonstrated in a ceremonial fashion and by way of signature, seal or any other form of deed of execution was too artificial to capture the informal and flexible manner in which international commerce is conducted. Thus, new insights in contract law emphasised the need to take account of the actual context of contracts, including the totality of facts and economic relations surrounding commercial transactions, in order to identify the rights and obligations of the parties in a business project. ${ }^{74}$

While contract law theory has challenged the artificial notion of contracts as distinct instant transactions and has highlighted the need for informality and contextualisation, arbitration law has remained adherent to neo-classical theories of contract law. These theories allow some scope for reasonable reliance and promissory estoppel, but they largely require that consent be demonstrated with a high degree of specificity at the time the contract is concluded. ${ }^{75}$ Indeed, for arbitration law on non-signatories, as for neo-classical theories on contract law, subsequent informal or contextual communications are mostly irrelevant. ${ }^{76}$

\footnotetext{
70 See for example in the US the influential work of I.R. Macneil, e.g. in 'The Many Futures of Contract' (1974) 47 Southern California Law Review 691, and 'Contracts: Adjustment of LongTerm Economic Relations under Classical, Neoclassical and Relational Contract Law', (19771978) 72 Northwestern University Law Review 854 and more recently in the UK the work of David Campbell, e.g. in D. Campbell, L. Mulcahy and Sally Wheeler (eds), Changing Concepts of Contract: Essays in Honour of Ian Macneil (Palgrave Macmilan 2013).

71 P.S. Atiyah, The Rise and Fall of Freedom of Contract (Oxford University Press 1985).

72 See Randy Barnett, 'The Richness of Contract Theory', (1999) 97 Mich. L. Rev. 1413-1429, reviewing Robert A. Hillman, The Richness of Contract Law: An Analysis And Critique Of Contemporary Theories Of Contract Law (1997). See also, Macneil, in 'Contracts: Adjustment of Long-Term Economic Relations under Classical, Neoclassical and Relational Contract Law', above (note 70), p. 882-83.

${ }_{73}$ Macneil, 'The Many Futures of Contract', above (note 70).

${ }^{74}$ Jay Feinman, 'Relational Contract Theory in Context', (1999-2000) 94 Nw. U. L. Rev. 737.

75 Luke Nottage, 'A Weathermap for International Arbitration: Mainly Sunny, Some Cloud, Possible Thunderstorms', Chapter 5 in Stavros Brekoulakis, Julian Lew and Loukas Mistelis (eds), The Evolution and Future of International Arbitration (Kluwer 2016).

76 This is the case at least in theory, because in practice (as the previous section demonstrated), courts and tribunals faced with the complexities of commercial reality, where parties often fail to consent to every term of a transaction including an arbitration clause, have often forcefully expanded the scope of 'consent' far beyond anything close to what the parties ever had in mind.
} 
One might suggest that arbitration law should develop a non-signatory theory based on informality and contextualisation. ${ }^{77}$ However, this suggestion would be misplaced. While the goal for modern contract law might be to move towards more relational theories in the future, the goal for arbitration law should be to retreat, at least to some extent, from contract law. While it is reasonable for contract law to develop theories that will better explain the way that complex contractual relationships work today, it is not reasonable for arbitration law to continue to assume that whatever works for contracts, should work for arbitration too.

Indeed, many of the limitations of the existing non-signatory theories owe much to the fact that they have been broadly borrowed from contract or corporate law, rather than been organically developed for arbitration. However, arbitration law is not a form of contract or corporate law; it is an autonomous legal field with a distinct nature and purpose. While the main question for corporate and contract law is whether a party is substantively liable, the main question for arbitration law is whether a tribunal has jurisdiction to resolve a certain dispute.

Legal theories originally developed to answer questions of liability used instead to answer questions of jurisdiction may provide us with the wrong answers. For example, the doctrine of lifting the corporate veil was originally developed and mainly used to determine whether a parent company or an individual can be held liable for the debts of a subsidiary. ${ }^{78}$ The theory was not designed to determine whether the non-signatory parent company should be bound by an arbitration agreement signed by its subsidiary. The former question is a matter of substance; the latter is a matter of jurisdiction.

While in theory the analysis for jurisdictional purposes can be 'analytically and practically distinct from the merits of a piercing action, ${ }^{19}$ in practice the decision of a arbitration tribunal to assume jurisdiction over a non-signatory parent under the doctrine of lifting the corporate veil will essentially determine the question of liability of the parent company too. It cannot be right, however, that a tribunal will assume jurisdiction over a non-signatory parent only when it is expected that the parent will be eventually found liable too. It is no surprising, thus, that international tribunals have been extremely reluctant to lift the veil of an arbitration agreement and assume jurisdiction over non-signatories, lest their decision on jurisdiction is perceived as a precursor of their decision on liability. ${ }^{80}$ It becomes obvious thus that while this theory makes good sense for corporate law, its suitability for arbitration purposes is questionable.

\footnotetext{
77 See for example, Keechang Kim and Jason Mitchenson, "Voluntary Third- Party Intervention in International Arbitration for Construction Disputes: A Contextual Approach to Jurisdictional Issues", Journal of International Arbitration, 30 (2013) 407.

${ }^{78}$ See P Blumberg, K Strasser, N Georgakopoulos, and E Gouvin, Blumberg on Corporate Groups (Aspen, 2005) ch 6.

${ }^{79}$ See John Fellas, 'Comments on Parties in International Arbitration', Chapter 11 in Stavros Brekoulakis, Julian Lew and Loukas Mistelis (eds), The Evolution and Future of International Arbitration (Kluwer 2016).

80 A rare example being Ad hoc award of 1991, (1992) 2 ASA Bull 202 (discussed in T Zuberbühler, 'Non-signatories and the Consensus to Arbitrate' (2008) 26(1) ASA Bull 30).
} 
For similar reasons, contract law theories, such as consent by conduct or even more modern theories such as contract by reliance or benefit, may be helpful to ascertain consent for substantive contracts but not necessarily for arbitration agreements. Commercial parties often participate in substantive contracts which they have not signed, either by negotiating or performing part of such contracts. In those circumstances, consent by conduct or ratification is conceivable. However, because of the nature and purpose of arbitration agreements, consent for arbitration by conduct is very difficult to ascertain, unless for example a signatory commences arbitration proceedings against a non-signatory who does not object to the jurisdiction of the tribunal and therefore consents, by conduct, to arbitration.

Arbitration doctrine has largely ignored these fundamental differences between arbitration agreements and arbitration law on the one hand, and ordinary contracts and contract law on the other. Arbitration law thus needs to develop a theory on non-signatories which is international and reflects the distinct jurisdictional nature and purpose of arbitration. The following section offers an alternative theoretical approach to resolve these problems, relying on the concept of dispute, which is the main essence and objective of any adjudicatory system, including international arbitration.

\section{A PROPOSAL FOR A GENERAL THEORY ON NON-SIGNATORIES BASED ON THE CONCEPT OF DISPUTE}

From the preceding discussion, it becomes apparent that the existing arbitration law on non-signatories exhibits considerable deficiencies in theory and fails to accommodate complex business transactions in practice.

International arbitration would benefit from a more coherent, more inclusive and intellectually more honest approach to non-signatories that would reflect the distinct jurisdictional nature of arbitration and would be better equipped to facilitate contemporary commerce. A general theory on nonsignatories in international arbitration is needed. Such a theory requires that the focus of examination in non-signatory disputes be shifted from consent-based to dispute-based analysis. Under this approach, what matters is not whether a nonsignatory has presumably consented to arbitration but whether and to what extent a non-signatory is actually implicated in the dispute before an arbitration tribunal.

While such a general theory needs to be further developed in future works, the following sections set out first, the test for arbitration tribunals to assume jurisdiction over non-signatories under a dispute-based theory; second, the underpinning justification for the emerging theory and, third, the legal basis for arbitration tribunals to assume jurisdiction over non-signatories under a dispute-based theory. Further, a number of potential objections to a disputebased theory are examined and some open questions requiring further work are identified. At the end, an overall assessment of the theory is offered. 


\section{A. A Dispute-based Test to Assume Jurisdiction over Non-Signatory Claims}

The concept of dispute is critical for the jurisdiction of international tribunals. Unless a dispute arises, an arbitration cannot come to life. Crucially, the scope and implications of a dispute, including whether it implicates nonsignatories, matter for the jurisdiction of arbitration tribunals. As experience from modern business transactions shows, non-signatories may become implicated, often inextricably, in a commercial project or a transaction in a number of different ways. ${ }^{81}$

Examples from real cases include the case of a non-signatory that conspires and colludes with a signatory to frustrate the rights and obligations of another signatory; ${ }^{22}$ the case of a non-signatory State or parent company that interferes with the performance of a contract between a state entity or a subsidiary and another company; 83 the case where the performance of a non-signatory under a guarantee contract depends on the non-performance of the underlying contract between two signatories; 84 the case where a signatory and a non-signatory are jointly liable vis-à-vis a signatory. ${ }^{85}$

In these examples, it is very likely that the resolution of the dispute in arbitration between the two signatories will depend on the conduct of the nonsignatory and will entail the examination of the non-signatory's rights and duties, or the examination of another contract involving the non-signatory. A claim by or against a non-signatory in these circumstances is thus an integral part of the dispute between the signatories, and arbitration tribunals should be able to look into such claim.

Accordingly, the proposed test for tribunals to assume jurisdiction over nonsignatories would be whether a non-signatory claim is inextricably implicated in a dispute submitted for arbitration. Admittedly, the inquiry as to whether a nonsignatory claim is inextricably implicated in a dispute is inevitably fact-specific and may differ with the circumstances of each case. ${ }^{86}$ However, the factual nature of the test does not necessarily render it discretionary or unpredictable. Indeed, a review of cases from different jurisdictions, which have acknowledged

\footnotetext{
${ }^{81}$ Cf section 1 English Arbitration Act providing 'the object of arbitration is to obtain the fair resolution of disputes'.

82 See for example, Ross v American Express Ross v American Express F 3d (2d Cir 2008) and PRM Energy Systems Inc. v. Primenergy, 592 F.3d 830 (8 ${ }^{\text {th }}$ Cir. 2010). See also in France Cour de Cassation Cass 1e civ, 11 June 1991, Orri v Lubrifiants Elf Aquitaine (1992) Rev Arb 73, with note D Cohen.

83 See for example, Dallah v Government of Pakistan, [2010] UKSC 46 and Interim Award of 23 September 1982, ICC Case No. 4131, Y.C.A. Vol. IX (1984), 131 and Clunet 1983, at 899.

${ }^{84}$ See for example, Choctaw Generation v American Home Assurance 271 F 3d 403 (2d Cir 2001) and the recent Stemcor UK Ltd v Global Steel Holdings Ltd and Pramod Mittal [2015] EWHC 363 (Comm).

85 See the Ashot Egiazaryan, Vitaly Gogokhiya v OJSC OEK Finance, The City of Moscow, [2015] EWHC 3532 (Comm).

${ }^{86}$ E.g. Smith Enron w Generation v American Home Assurance 271 F 3d 403 (2d Cir 2001).
} 
the importance of the concept of dispute in non-signatory cases, provides useful guidance as to the minimum requirements of the test.

To begin with, an important indication that a non-signatory claim is inextricably implicated in a dispute between two signatories in arbitration is the question of the non-signatory's liability. If liability of the non-signatory depends on the liability of a signatory, the question of liability for these two parties may in reality be a single issue, which could be addressed by a single tribunal.

For example, in the decision of the High Court of Singapore in Yee Hong Pte Ltd $v$ Tan Chye Hee Andrew \& Ho Bee Development Pte Ltd, ${ }^{87}$ a developer of a condominium project entered into separate contracts with a contractor and an architect. In the course of the construction project, the architect certified that there was considerable delay on the part of the contractor and that, therefore, the contractor was liable to the developer for liquidated damages. The contractor brought a lawsuit in Singapore against the architect on the basis that it had failed to act fairly and impartially in administering the contract and that it had wrongfully issued a delay certificate. The architect joined the developer in the lawsuit and, relying on the arbitration agreement in the contract with the developer, requested the court to refer the contractor's claim to arbitration. Noting that an earlier action of the contractor against the developer for extension of time had already been stayed on the basis of an arbitration agreement in the construction contract, the High Court of Singapore held that the two actions of the contractor against the architect and the developer should be decided in a single tripartite arbitration between the developer, the architect and the main contractor.

The court highlighted the fact that the liability of the architect against the non-signatory contractor depended on the determination of the dispute between the contractor and the developer about whether the former was entitled in extension of time. The court noted:

It is highly unsatisfactory for one dispute (between the [contractor] and the [developer]) to be referred to arbitration and for another (between the [contractor] and the [architect]) to be litigated separately, when both disputes arose out of the same project. Such a state of affairs would not determine the whole dispute among all three parties. Who would ultimately decide the dispute concerning extensions of time and whether the delay certificate was properly issued? ${ }^{88}$ (emphasis added)

Another important element of the test will be the existence of a close relationship between a non-signatory and a signatory party. The closer the contractual or corporate links between them, the more likely will be for an arbitration tribunal to assume jurisdiction over the non-signatory claim. For example, in deciding whether a claim by a signatory against a non-signatory charterer should be referred to arbitration in England, the Federal Court of

87 Yee Hong Pte Ltd v Tan Chye Hee Andrew \& Ho Bee Development Pte Ltd [2005] 4 SLR 398.

88 Ibid, at 20. Cf ICC case no 9762 of 2001, ICC case no 9762 of 2001, (2004) 29 YBCA 26. Cf also, Morrie Mages v Thrifty Corporation 916 F 2d 402 (7th Cir 1990). 
Australia in BHPB Freight Pty Ltd v Cosco Oceania Chartering Pty Ltd held that one of the conditions for a non-signatory to claim 'through or under a signatory' party ${ }^{89}$ is that 'a relationship of sufficient proximity' between the signatory and the non-signatory must exist. ${ }^{90}$ Australian courts in other cases have found that a 'relationship of sufficient proximity' existed in cases where a claim has been brought by a non-signatory subsidiary and a signatory parent company (or against a non-signatory parent company and a signatory subsidiary). ${ }^{91}$ That was, for example, the case in Flint Ink NZ Ltd v Huhtamaki Australia Pty Ltd, where a non-signatory subsidiary was held to be bound by an arbitration agreement on the basis that the non-signatory was claiming 'through or under' a company within the same corporate group which had signed a contract, including an arbitration clause, with a seller for the purchase of ink. ${ }^{92}$

The inquiry of Australian courts about 'a relationship of sufficient proximity' between the signatory and the non-signatory party echoes the inquiry of many arbitration tribunals about 'group structure' in the context of the 'group of companies' doctrine, and the inquiry of many US Courts about 'identity of interests' 93 or 'integral relationship' 94 between non-signatory parent companies and signatory subsidiaries under the arbitration estoppel doctrine.

A third element of the proposed test will be the existence of intertwined claims and contracts between signatories and non-signatories. Against a background of closely interrelated substantive contracts, a number of arbitration tribunals and national courts have found that a signatory should be enjoined to arbitrate its claim against a non-signatory (and vice versa) if the underlying substantive contracts and claims by and against signatories and non-signatories are closely interrelated.

For example, in the ICC case no 9762 of 2001,95 a contractor brought a claim against, among others, the Ministry of Agriculture and Food of State Z that was a party to the contract containing an ICC arbitration agreement, and a claim against the non-signatory State Z. The tribunal assumed jurisdiction over both the claim against the signatory Ministry of Agriculture and Food and the nonsignatory State $\mathrm{Z}$, on the basis that the claims against the signagory and the nonsignatory were interrelated as both respondents were potentially co-liable vis-àvis the claimant. The tribunal noted that: 'The right of a claimant to act against all

\footnotetext{
${ }^{89}$ As section 7(4) of the Australian International Arbitration Act 1974 provides.

90 (2008) FCR 169 (Federal Court of Australia), at para. 15. See further James Morrison and Luke Nottage Country Report on Australia for Simon Greenberg, Christopher Kee and Romesh Weeramantry, International Commercial Arbitration: An Asia-Pacific Perspective (2 ${ }^{\text {nd }}$ Ed) (CUP 2011) available at http://papers.ssrn.com/sol3/papers.cfm?abstract_id=2514124.

${ }^{91}$ Although this factor alone may not necessarily suffice, see McHutchison $v$ Western Research and Development Ltd [2004] FCA 1234 (Federal Court of Australia).

92 Flint Ink NZ Ltd v Huhtamaki Australia Pty Ltd [2014] VSCA 166.

93 Smith/Enron Cogeneration v Smith Cogeneration Int'l 198 F 3d 88 (2d Cir 1999), at 98.

94 Sunkist Soft Drinks v Sunkist Growers 10 F 3d 753 (11th Cir 1981). See also JJ Ryan \& Sons v Rhone Poulenc Textile 863 F 2d 315, 320-1 (4th Cir 1988) and Astra Oil Company v. Rover Navigation, 344 F.3d 276 (2d Cir. 2003).

95 ICC case no 9762 of 2001, (2004) 29 YBCA 26.
} 
possible responsible subjects cannot be denied'96 and that 'no distinction can be made between the liability of first respondent [the Ministry] and third respondent [State Z] (if any).' ${ }^{\prime 7}$ The tribunal recognised that the scope of the tribunal's jurisdiction must be determined in light of the substantive background of the dispute submitted to arbitration, and that the substantive commitments undertaken by signatories and non-signatories are relevant for a tribunal to assume jurisdiction over a non-signatory:

[. . .] the mandatory force of the arbitration clause (or arbitration agreement) cannot be dissociated from that of the substantive contractual commitments. This may be the case of companies belonging to the same 'group of companies', whenever there is a sufficient evidence of the global liability of the 'group'. This may be the case of an individual partner being bound by an arbitration clause signed by a general partnership. This may also be the case of States when engaging in transactions of an economic nature through one of their administrative bodies, or even through a separate legal entity provided, in this last case, that the State has full control over it and is bound by the acts of it. ${ }^{98}$

Similarly, in the context of fraud claims against signatories and nonsignatories or claims for unlawful interference by a non-signatory with a contract between two signatories, the US courts have repeatedly held that all claims by and against signatories and non-signatories should be heard by a single arbitration tribunal especially if the alleged collusive actions or claims for interference are intimately founded in and intertwined with the underlying contract obligations between the signatories. ${ }^{99}$

The above should be qualified by the following caveat. If the signatories have agreed to arbitrate only very specific claims that might arise between the two of them, it would not be possible for a tribunal to assume jurisdiction over non-signatory claims. A narrowly drafted arbitration agreement will provide tribunals will narrow scope of authority and disputes with wider commercial implications, including on non-signatories, will necessarily fall outside the tribunal's jurisdiction. However, widely drafted arbitration agreements may cover disputes that arise out of complex projects implicating non-signatory claims.

The role of a broad arbitration agreement in non-signatory claims has been confirmed by several national courts. For example, in JLM v Stolt-Nielsen the US Second Circuit focused on the scope of the arbitration agreement in the charterparty to accept jurisdiction over a non-signatory, noting:

\footnotetext{
96 Ibid, para 55 of the award.

97 Ibid, para 58 of the award.

98 Ibid, at paras 49-55. See similar decisions by national courts in.

${ }^{99}$ See for example PRM Energy Systems Inc. v. Primenergy, 592 F.3d 830 (8th Cir. 2010) and earlier decisions in Choctaw Generation Ltd. v. Am. Home Assurance, 271 F.3d 403 (2nd Cir 2001), Grigson v. Creative Artists Agency, L.L.C., 210 F.3d 524, 527 (5th Cir 2000), McBro Planning Development $v$ Triangle Electrical Construction 741 F 2d 342 (11th Cir 1984), and Hughes Masonry v Greater Clark County School Bldg 659 F 2d 836 (7th Cir 1981).
} 
[R]ecognizing there is some range in the breadth of arbitration clauses, a court should classify the particular clause as either broad or narrow. [...] Where the arbitration clause is narrow, a collateral matter will generally be ruled beyond its purview. Where the arbitration clause is broad, there arises a presumption of arbitrability and arbitration of even a collateral matter will be ordered if the claim alleged implicates issues of contract construction or the parties' rights and obligations under it. ${ }^{100}$

Accordingly, the court concluded: 'Because the [present] arbitration clause is broad, its coverage extends to "collateral matters"'101 (i.e. the claim of the nonsignatory against the signatory). ${ }^{102}$

The above are some factors that can be taken into account by international tribunals to determine the extent to which a non-signatory is implicated in the dispute between two signatories, and therefore the propriety of assuming jurisdiction over non-signatories. In all cases, the inquiry should focus on the scope of the dispute before them and its commercial implications on both signatories and non-signatories.

\section{B. The Underpinning Justification for the Emerging Theory}

Depending on the factual circumstances, the underpinning justification for the emerging theory lies with considerations of equity, access to justice and due process. Equity considerations, for example, will support the joinder of a nonsignatory in arbitration in circumstances similar to the Dallah scenario. While contract-based analysis by the Dallah tribunal as well as the French Court of Appeal and the UK Supreme Court wrongly focused on whether the Government of Pakistan consented by conduct to arbitration, the factual circumstances of the dispute give rise to obvious considerations of equity. It is clearly troubling when a State establishes a state-entity to sign a contract, including an arbitration clause, which the State negotiates, only for the state-entity to cease to exist by the time a dispute arises. With the state-entity defunct, whether the claimant should be able to bring a claim against the State in arbitration, rather than the State's own courts, is not a matter of consent; it is a matter of equity, especially when the State is strongly implicated in the underlying contract and the ensuing dispute.

Similar considerations will underpin circumstances where a parent nonsignatory company seeks to avoid arbitration when the signatory subsidiary has become insolvent at the time the dispute arises or has been left with no assets for the claimant to recover damages in arbitration. ${ }^{103}$

\footnotetext{
100 JLM Industries v Stolt-Nielsen, 387 F 3d 163, 2004 (2d Cir 2004) at 172, citing Louis Dreyfus Negoce SA v Blystad Shipping \& Trading Inc 252 F 3d 218, 224 (2d Cir 2001).

101 Ibid.

102 See also MS Dealer Serv Corp v Franklin 177 F 3d 942, 947 (11th Cir 1999) and Meyer v. WMCO-GP, 211 SW3d 302, 305 (Tex. 2006).

103 Cf also Aubrey Thomas, "Non-Signatories in Arbitration: a Good Faith Analysis" 14 Lewis \& Clark L. Rev. 2010, 953, who proposes that national courts should adopt equitable principles, such as the principle of good faith, to determine whether a non-signatory should arbitrate a dispute.
} 
There are other circumstances where a non-signatory will have an interest relating to the property or transaction that is the subject of the arbitration and it is so situated that the disposition of the arbitration may, as a practical matter, impair or impede the non-signatory's ability to protect that interest, not least because the non-signatory is not adequately represented by any of the signatory parties to the arbitration. ${ }^{104}$ In these circumstances, allowing a non-signatory to participate in an arbitration between two signatories is the only way for the nonsignatory to protect its right to access to justice, 105 especially as non-signatories are often unable to commence court proceedings to protect their interests against signatories. Indeed, on several occasions, national courts have stayed proceedings or declined jurisdiction over a claim by a non-signatory on the basis that a closely related claim is already pending in arbitration between the signatories. 106 Requiring a non-signatory party to wait until the arbitration between the signatories is concluded and, at the same time, prohibiting the nonsignatory from participating in the arbitration that is likely to affect its legal and commercial interests, undermines its right to access to justice and its right to be heard. ${ }^{107}$ Even if the non-signatory is able to proceed with its court claim after the conclusion of the arbitration between the signatories, it is likely that the nonsignatory's interests would have already been affected, potentially irreversibly, by the outcome of the arbitration which the non-signatory was unable to participate.

Assume, for example, the case where a litigation between a subcontractor and a main contractor is stayed until the arbitration between the main contractor and the employer is concluded. If the arbitrators decide that the main contractor is liable to the employer for delays in delivery of the works, actually performed by the subcontractor, the subsequent litigation between the main contractor and the subcontractor is likely to be moot. The ability of the subcontractor to set out its case in full will be considerably curtailed as a result of the outcome of the arbitration, which the subcontractor had no opportunity to influence. ${ }^{108}$

In this respect, in a number of jurisdictions, an arbitral award between two signatories may produce preclusive effects that apply to issues of fact or law ('issue preclusion' in the US or 'collateral estoppel' in England"). ${ }^{109}$ Courts in different jurisdictions have held that, under certain circumstances, a signatory

\footnotetext{
104 Strong above (note 8).

105 See Strong above (note 8) 979 who argues for the right of the non-signatory to intervene on the basis of a broader construction of the principle of equality of the parties, a term who, as she convincingly argues, may include the non-signatory.

106 See for example, Morrie Mages v Thrifty Corporation 916 F 2d 402 (7th Cir 1990).

107 See Matti S. Kurkela and Santu Turunen, "Due Process in International Commercial Arbitration", (Second Edition), (Oxford University Press 2010), at 186.

108 Strong above (note 8) 983.

109 See more generally, Stavros Brekoulakis, "The Effect of an International Arbitral Award and Third Parties", American
} 
can rely on the issue preclusion effect of an arbitration award against a nonsignatory in subsequent arbitration or litigation. ${ }^{110}$

It is difficult to justify, in terms of justice to access and due process, how a non-signatory can be the subject of preclusive effect from an arbitration between two signatories in which the non-signatory is denied access as a matter of principle. Under French law, a non-signatory can challenge any adverse effect of an award in domestic arbitration under the legal construct of tierce opposition. ${ }^{111}$ Notably, the French Tribunal de Grande Instance de Paris, very recently, extended the tierce opposition recourse against international awards, rightly noting that considerations of access to justice and fundamental principles of due process require that an affected non-signatory party can, albeit exceptionally, oppose the enforcement of an international award between two signatories. ${ }^{112}$ However, the recourse of tierce opposition or a similar legal construct hardly exist outside France, leaving non-signatories generally unable to have access to an arbitration which may affect their interests in the first place or challenge the ensuing arbitration award at the end.

In other cases, in the absence of the non-signatory, it may be unlikely that complete relief is accorded among the signatories in arbitration. In these cases, unless the non-signatory is joined in the arbitration, the right to access to justice for one of the signatories may be impaired.113

National litigation laws are well familiar with these cases and the underlying considerations relating to access to justice and due process. Indeed, almost all national litigation systems set out effective procedural mechanisms, often of mandatory nature, to allow a third party or one of the original parties to protect their rights in a court. For example, the US Federal Rules of Civil Proceedings provide for intervention as a matter of right, ${ }^{114}$ as well as for mandatory joinder of a third party who is so closely interrelated in the dispute between the original

110 In the US for example, preclusive effect can be produced if the: "Issue Preclusion] is permissible as to a given issue if [:] (1) the identical issue was raised in a previous proceeding; (2) the issue was actually litigated and decided in the previous proceeding; (3) the party had a full and fair opportunity to litigate the issue; [] (4) the resolution of the issue was necessary to support a valid and final judgment on the merits[;] . . . [and (5)] application of the doctrine is fair." Bear, Stearns \& Co., Inc. v. 1109580 Ontario, Inc., 409 F.3d 87, 91 (2d Cir. 2005] [check]. See also Executive Risk Indem, Inc v Jones 89 Cal Rptr 3d 747 (Cal Ct App 2009) where the California Court of Appeal found that an arbitration award between an insured and a financial firm produced issue preclusion against the non-signatory insurance company in relation to liability and the amount of damages the insured has suffered. See also in France the Cour de Cassation, 23 January 2007, Prodim v Distribution Casino France (2007) Rev Arb 135 which also found that an arbitral award can produce preclusive effects against non-signatories. The same was held by English courts in Stargas SpA v Petredec Ltd (The Sargasso) [1994] 1 Lloyd's Rep 412.

111 See the French Code de Civil Procedure Art. 583-585.

112 See decision of 25 April 2017, 5ème chambre 1ère section No RG: 15/17869. "Le droit effectif au juge et l'exigence d'un procès équitable, méconnus par l' impossibilité pour le tiers lésé de faire tierce opposition à une sentence arbitrale internationale, ne peut être assuré que par cette voie de recours exceptionnelle."

113 Ibid at 982, where she conceptualises the right of the signatory to join a non-signatory in terms of its right to have a full opportunity to be heard 982 .

114 US Fed.R.C.P. r.24(a); 
parties that its presence in the litigation is considered necessary. ${ }^{115}$ The English Civil Procedure Rules require that where a third party is jointly entitled to a remedy with one of the original parties, the third party must be joined in the litigation as a matter of necessity. ${ }^{116}$ The French Code of Civil Procedure provides that a third party will be forced to join the court proceedings when the final judgment will bind not only the original parties but the third party too. ${ }^{117}$

While some of the underpinning considerations of third-party litigation mechanisms relate to procedural efficiency and may not be readily applicable in arbitration, other considerations relate to the protection of legitimate interests of the original parties and third parties, as well as the protection of their right to access to justice and due process. ${ }^{118}$

This kind of considerations is equally important for litigation and arbitration. In fact, in some cases, considerations favouring participation of non-signatories may be stronger in arbitration than in litigation. For example, under certain circumstances, national litigation laws provide that unless a third party, who is classified as indispensable, is joined in litigation, litigation cannot proceed. ${ }^{119}$ While in litigation, national courts have the statutory power to dismiss a claim in the absence of the indispensable third party, arbitration tribunals do not have similar powers. The contractual and statutory duty of arbitrators is to exercise their mandate and decide the dispute. ${ }^{120}$ In such circumstances, joining the nonsignatory indispensable party in arbitration would be the only option for the signatories' right to obtain relief in arbitration and exercise their right to access to justice.

In sum, there are a number of important considerations favouring a broad mechanism for participation of non-signatories in arbitration. The fact that in arbitration party autonomy is the overriding consideration should not of itself prevent us, as a matter of principle, from accounting for these considerations in arbitration doctrine, and from seeking ways to include non-signatories in the

\footnotetext{
115 US Fed.R.C.P. r.19.

116 English Civil Procedural Rules 19.3(1): "where a claimant claims a remedy to which some other person is jointly entitled with him, all persons jointly entitled to the remedy must be parties unless the court orders otherwise".

${ }^{117}$ Art 331(2). See also Art 332(1): "le juge peut inviter les parties a mettre en cause tous les intéresses dont la présence luit paraît nécessaire a la solution du litige".

118 US Fed.R.C.P r.19.

119 US Fed.R.C.P. r.19. Under rule concerning joinder, party shall be joined as necessary party if (1) in person's absence complete relief cannot be accorded among those already parties, or (2) person claims interest in subject of action and is so situated that disposition of action in person's absence may, as practical matter, impair person's ability to protect that interest or leave any of the persons already parties subject to substantial risk of incurring double, multiple, or otherwise inconsistent obligations by reason of claimed interest. For an overview of the historical underpinnings through the modern application of the US Fed.R.C.P. r.19 see Brandon Coyle, "The Proper Standard of Review for Required Party Determinations Under Federal Rule of Civil Procedure 19" 84 Fordham L. Rev. 1117 2015-2016.

$120 \mathrm{Cf}$ for example, Article 42 of the ICC Arbitration Rules providing that the arbitrators have a duty to render an enforceable award, and s.24(1) of the English Arbitration Act providing that an arbitrator who fails to conduct the arbitration can be removed by the English courts.
} 
arbitration process in appropriate circumstances. As in other legal fields, it is appropriate to be able to balance the parties' will against fundamental principles of access to justice, equity and due process. ${ }^{121}$

\section{Legal basis for the implementation of the emerging theory}

The implementation of the proposed theory on non-signatories will require a reform of the current arbitration law. The safest way to effect a reform on this matter would be through legislation or national courts. If legislators or national courts, for the reasons explained in the preceding section, decide that non-signatories should be granted some ability to participate in the arbitration proceedings, they can develop a legal rule whereby arbitration tribunals will have jurisdiction to hear non-signatory claims which are "inextricably linked" with the dispute between two signatories, or on the basis of another test to that effect.

As already mentioned, there is currently a confirmed policy favouring arbitration as the preferred method for resolving disputes arising out of international commercial transactions. For legislators and national courts to take a step further and establish international commercial arbitration as the default method for disputes arising out of complex multiparty transactions would be a perfectly justifiable policy decision.

Admittedly, expanding the pro-arbitration policy to non-signatories may appear to be in tension with the right to court trial, which in some jurisdictions is constitutionally protected. ${ }^{122}$ For that reason, the suggested reform should be reserved for entirely commercial disputes, and exclude consumers, employees or any category of non-commercial disputes involving groups of litigants who require legislative or constitutional protection. In any case, with the remarkable growth of international arbitration in the last thirty years, the idea that national courts are the natural adjudicatory forum is becoming increasingly difficult to defend, especially for commercial disputes. ${ }^{123}$ International arbitration can provide commercial parties with an alternative route to justice which should not be constitutionally problematic.

Relatedly, there have recently been suggestions by prominent arbitration practitioners and scholars that States should take steps to reset the default of all international commercial disputes from national litigation to international arbitration. ${ }^{124}$ Most notably, Gary Born has convincingly argued for the

\footnotetext{
121 Strong above (note 8) 995.

${ }^{122}$ In the US for example there is a right to jury trial [find citation to support that] [cite also the article for access to justice], although see the recent decision in Kindred Nursing Centers Limited v. Clark (No. 16-32, May 15, 2017), where the US Supreme Court held (with a wide majority of 71) that state rules requiring a "clear statement" in a agency agreement waiving the right to a jury trial in court were violating the US Federal Arbitration Act, and were therefore unenforceable.

123 See Pinsolle above (note 124).

124 Gary Born, ('BIT's BAT's and Buts' (available at: https://www.wilmerhale.com/uploadedFiles/Shared_Content/Editorial/News/Documents/BITs -BATs-and-Buts.pdf). See also Giles Cuniberti, 'Beyond Contract: The Case for Default Arbitration in International Commercial Disputes', (2009) 32 Fordham Int'l L.J. 417, 472 and see Philippe,
} 
development of international arbitration treaties, bilateral or multilateral, providing that certain categories of commercial disputes between nationals, including governmental agencies, of the signatory States shall be resolved, as a default mechanism, by international commercial arbitration. ${ }^{125}$

A bilateral arbitration treaty resetting the default from national litigation to international commercial arbitration would provide the power to international commercial tribunals to entertain non-signatory claims under the proposed unifying theory on non-signatories, as explicit party consent to arbitrate would not be required.

If the suggested reform is not effected by national courts or legislation at national or international level, it can, arguably, be effected by international commercial tribunals. This would require arbitration tribunals to take a broad approach to their own jurisdiction. This approach will involve examination of two questions: first, whether the tribunal has jurisdiction over the dispute between two signatories. This is a threshold jurisdictional question that involves examination of whether a valid arbitration agreement exists between the two signatories. To answer this question, the arbitration tribunal will have to examine the formal and substantive requirements of validity which apply to every arbitration agreement.

If the tribunal finds that a valid arbitration agreement exists between two signatories, the tribunal will subsequently have to examine whether it has jurisdiction over a non-signatory claim. To answer this question, the arbitration tribunal will have to examine whether a non-signatory claim is part of the main dispute for which the tribunal already has jurisdiction.

If the tribunal finds that the non-signatory claim is inextricably implicated in the dispute before it, it may decide to assume jurisdiction over the nonsignatory claim as part of its jurisdiction over the dispute between the two signatories.

Such a broad approach to arbitration tribunals' jurisdiction is not novel. It is supported by theories emphasising the adjudicatory character of arbitration. According to these theories, arbitration is not a form of contract law; it is a decision making process that bears characteristics of adjudication. ${ }^{126}$ From this viewpoint, arbitrators perform an adjudicative function that can justify a broad approach to their own jurisdiction, which would allow them to dispose of every claim that is an integral part of the dispute in arbitration, including some nonsignatory claims.

\section{Potential objections to the emerging theory}

Pinsolle, 'A French View on the Application of the Arbitration Agreement to Non-Signatories', Chapter 12 in Stavros Brekoulakis et al. (eds), The Evolution and Future of International Arbitration (Kluwer 2016).

125 Born, Ibid.

126 Born above (37) 284. 
Admittedly there are a number of reasons that might give us pause in reflecting upon the proposed theory. Three are the most important ones. First, certain commentators suggest that the most appropriate way to deal with nonsignatories is to leave the matter to the parties to decide at the drafting stage. However, this suggestion is predicated upon an ideal scenario of two experienced commercial parties entering into long and careful negotiations through specialised law firms. Commercial reality can be very different and often entails very short timeframes and informal circumstances of negotiations with parties entering into standard forms of contract, where an arbitration clause is only one of several terms. ${ }^{127}$ In other circumstances, the involvement of a nonsignatory in the underlying transaction and the ensuing dispute is not obvious or cannot be anticipated at the time the transaction in completed, especially in longterm relational contracts. ${ }^{128}$

Importantly, the suggestion that non-signatories should be dealt with by parties at the drafting stage simply begs the question. The reality is that in practice, as the large number of non-signatory cases demonstrate, parties fail to deal with non-signatories at the time they enter into a contract. However, this is not a valid reason to prevent us from seeking to address important theoretical and practical problems arising out of the failure of the parties to provide for nonsignatories at the drafting stage.

Second, and relatedly, there is the suggestion that the emerging theory might be inconsistent with party consent and party autonomy, which have traditionally been the fundamental basis for international commercial arbitration. However, a unifying theory based on the concept of dispute does not suggest a radical departure from consent, at least in the manner consent is currently conceived by the existing non-signatory theories.

As already demonstrated, arbitration tribunals and national courts routinely rely on a broad concept of constructive consent for arbitration in disputes involving non-signatories. However, as explained above, the proposition that consent for the underlying contract necessarily entails consent for arbitration too is problematic and difficult to reconcile with the very idea of consent.

Understandably, the existing non-signatory theories have relied on constructive consent in order to extend arbitration agreements to commercially relevant non-signatories. At the same time, however, the 'sacrosanct' principle of consent for arbitration is already compromised under these theories. The proposed theory on non-signatories has the same objective as the existing nonsignatory theories, namely to involve commercially relevant non-signatories in arbitration. However, the suggested theory is intellectually more honest in recognising from the outset that traditional concepts of consent cannot always work satisfactorily for disputes involving non-signatories. It thus suggests shifting the focus of analysis from the concept of 'consent' to that of 'dispute'.

127 This is typically the case, for example, in maritime, insurance and sale of goods transactions.

128 Strong above (note 8) 995. 
Relatedly, if we turn our focus on the concept of 'dispute', we will realise that non-signatories are not usually strangers to the dispute between two signatories. They are often at the heart of both the underlying commercial transaction and the ensuing dispute between the signatories. As discussed in detail above, the typical cases of non-signatories include the non-signatory State or parent company which are involved in a project through a signatory governmental agency or subsidiary. Such non-signatories are usually heavily engaged in various stages of the commercial transaction and often have good knowledge of its terms, including an arbitration agreement. While their involvement in the commercial transaction and knowledge of the existence of an arbitration agreement are not sufficient factors to ascertain consent for arbitration, as the existing non-signatory theories wrongly suggest, these factors provide important justification for the participation of non-signatories in arbitration through non consent-based analysis.

The third important objection involves the question of enforceability of an award that has decided on a non-signatory claim on the basis of the proposed theory. The issue of enforceability relates back to the discussion on the legal basis for the implementation of the proposed theory. If legislation or national courts at the seat of arbitration have adopted a legal rule giving tribunals the power to decide non-signatory claims that are "inextricably implicated" in the dispute between two signatories, the award should clearly be enforceable. Unless the courts of the place of enforcement classify the objection against the award as a matter of public policy, which pursuant to Article V(2)(b) of the United Nations Convention for the Recognition and Enforcement of Foreign Arbitral Awards (the "New York Convention") ${ }^{129}$ will be determined by the law of the place of enforcement, any other objection under Article V(1) of the New York Convention will be decided mainly by reference to the law of the seat of arbitration. ${ }^{130}$

If a tribunal decides to hear a non-signatory claim without the existence of a legal rule expressively providing tribunals with such power, the outcome of the enforceability decision will admittedly depend on the approach of the enforcement courts. If the enforcement courts remain adherent to a consentbased analysis, reviewing the award on the basis of whether the non-signatory consented to arbitration (under Article V(1)(a) of the New York Convention), the award will most likely be refused enforcement.

\footnotetext{
${ }^{129}$ Article V2(b) of the New York Convention provides: "2. Recognition and enforcement of an arbitral award may also be refused if the competent authority in the country where recognition and enforcement is sought finds that: [....]

(b) The recognition or enforcement of the award would be contrary to the public policy of that country."

130 See for example, Article V1(a) of the New York Convention provides: "Recognition and enforcement of the award may be refused, at the request of the party against whom it is invoked, only if that party furnishes to the competent authority where the recognition and enforcement is sought, proof that: (a) The parties to the agreement referred to in article II were, under the law applicable to them, under some incapacity, or the said agreement is not valid under the law to which the parties have subjected it or, failing any indication thereon, under the law of the country where the award was made".
} 
However, if the enforcement courts decide to take a dispute-based approach, as proposed here, they could and should review the award on the basis of whether the non-signatory claim falls within the jurisdiction of the arbitration tribunal. This inquiry should focus on whether the non-signatory claim was part of the dispute before the arbitration tribunal and will fall under Article V(1)(c) of the New York Convention which refers to the scope of jurisdiction of the arbitration tribunal. ${ }^{131}$ If the enforcement courts, under this approach, agree with the tribunal's decision that the non-signatory claim was part of the original dispute, the award should be enforced.

Whether the objections above outweigh the advantages of the proposed theory is discussed at the final section below.

\section{E. Concluding remarks: the advantages of the emerging theory and open questions requiring future work}

The suggested theory exhibits important advantages over the existing nonsignatory theories. In the first place, it can enhance certainty and predictability with regard to the role of non-signatories in international business transactions. Currently whether a non-signatory will be bound by an arbitration agreement depends on a wide range of diverging non-signatory doctrines. As already explained, most of these doctrines, such as apparent authority, piercing the corporate veil and group of companies, have a narrow scope and rely on technical, often stringent, requirements. In attempting to persuade arbitration tribunals to assume jurisdiction over non-signatories, parties typically rely on several disparate non-signatory doctrines. ${ }^{132}$ However, commercial reality often fails to fit in the constraints of any of the non-signatory doctrines, frustrating claimants' most reasonable attempts to bring a non-signatory before an arbitration tribunal.

What is further problematic is that each of the non-signatory doctrines is subject to very different, and often contentious, conflict-of-law approaches. ${ }^{133}$ For example, the question of whether a non-signatory party will be bound by an arbitration agreement can be decided under a number of national laws, including the law of the arbitration clause or the law of the main contract (for the theory of

\footnotetext{
131 Article V1(c) of the New York Convention provides: "Recognition and enforcement of the award may be refused, at the request of the party against whom it is invoked, only if that party furnishes to the competent authority where the recognition and enforcement is sought, proof that: (c) The award deals with a difference not contemplated by or not falling within the terms of the submission to arbitration, or it contains decisions on matters beyond the scope of the submission to arbitration, provided that, if the decisions on matters submitted to arbitration can be separated from those not so submitted, that part of the award which contains decisions on matters submitted to arbitration may be recognized and enforced."

132 To refer to a characteristic example in the case of Bridas v. Government of Turkmenistan, 345 F.3d 347 (5 $5^{\text {th }}$ Cir. 2003), the claimant relied alternatively upon several third-party theories, including agency, instrumentality, apparent authority, alter ego, third-party beneficiary, theory of equitable estoppel, to prove that the government of Turkmenistan was bound by an arbitration clause signed by Turkmenneft, formed and owned by the government of Turkmenistan.

133 See Silva Romero \& Saffer (note 6).
} 
assignment and third-party beneficiary), ${ }^{134}$ the law of the agent (for the theory of representation), 135 the law of the seat of arbitration or the law of the company (for the theory of piercing the corporate veil). ${ }^{136}$

Importantly, the various doctrines on non-signatories are not consistent across national jurisdictions. ${ }^{137}$ Accordingly, a national court that takes a broad approach to non-signatories, perhaps at the initial stages of arbitration (allowing the non-signatory to be brought in an arbitration) may lead to enforceability issues if the award seeks enforcement in a jurisdiction that takes a narrow approach to non-signatories. Indeed, as explained above, numerous awards assuming jurisdiction over non-signatories have been set aside and prominent courts have taken diametrically opposing views on whether the same facts suggest that a non-signatory has consented to arbitrate. Eventually, the multiplicity of non-signatory doctrines and national laws on non-signatories in different jurisdictions has led to uncertainty and fragmentation of arbitration law on an important legal issue.

By contrast, the proposed theory provides a unifying legal basis for tribunals to determine whether to assume jurisdiction over a non-signatory under a single test. While the proposed test under the emerging theory will require further refinement by tribunals and national courts, unified transnational standards will gradually develop to provide more certainty and predictability as to when a nonsignatory may participate in an arbitration.

There are of course a number of questions that remain open in relation to the suggested theory. For example, one interesting question would be whether the test for tribunals to assume jurisdiction over non-signatory claims should be stated as a legal rule (as discussed above) or as a more flexible test that involves a balancing exercise. The latter can provide tribunals with some discretion to look into the justifications behind the test, notably considerations about equity, access to justice and due process, before deciding whether to extend their jurisdiction on a non-signatory. For example, tribunals may examine whether a non-signatory has been invited to join the arbitration but has unreasonably refused to do so; whether the signatory subsidiary has ceased to exist or has become insolvent; whether the signatory claimant has no realistic alternative route to justice but to commence arbitration against a non-signatory; or whether, unless a non-signatory participates in the arbitration, no complete relief can be accorded among the signatories. More practical factors may also be taken into account under a balancing exercise test, such as the anticipated increased cost and delay in case of participation of the non-signatory or whether

\footnotetext{
134 For assignment see D. Girsberger, 'The Law Applicable to the Assignment of Claims Subject to an Arbitration Agreement' in F Ferrari and S Kröll (eds), Conflict of Laws in International Arbitration (2010) 387; for third-party beneficiary, see Born, above (note 37) p. 1457 and $\mathrm{Am}$ Patriot Ins Agency v Mut Risk Mgt 364 F 3d 884, 890 (7th Cir 2004).

135 Cf Art.6 of the 1978 Hague Convention on the Law Applicable to Agency.

136 ICC 10758 of 2000 and ICC 7626 of 1995.

137 Cf Aubrey Thomas, "Non-Signatories in Arbitration: a Good Faith Analysis" 14 Lewis \& Clark L. Rev. 2010, 953, who suggests the application of the principle of good faith by the US courts to determine whether tribunals should extend their jurisdiction to non-signatories.
} 
confidentiality may be compromised if a non-signatory is joined in an arbitration between two signatories.

While a legal rule accounts for more certainty, a balancing exercise may provide for a more expedient test.

Another question that will require further work is the question of which law should guide the tribunal's decision on whether to assume jurisdiction over a non-signatory claim under the suggested theory. There are a number of possible options, including the law of the seat of the arbitration or the law of the substantive contract, especially since the suggested test brings the inquiry closer to the actual commercial transaction. However, the more appealing option would be the development of international standards on non-signatory conduct that transcend national laws.

The suggestion for the development of transnational standards on nonsignatories should not be perceived as a facile attempt to escape complex conflict of laws questions. International arbitration has traditionally been a fertile laboratory for the development of transnational legal rules in a number of areas, although notably not for non-signatories. ${ }^{138}$ The broadly relaxed relationship between international arbitration and national laws, including the national law of the seat of arbitration, ${ }^{139}$ allows arbitration tribunals to identify transnational legal standards that emerge from commercial practices and make sense for business people. The development of transnational legal rules on non-signatories will thus enhance certainty and predictability on the kind of non-signatory conduct that may allow tribunals to assume jurisdiction over non-signatory claims.

Overall, the traditional theories on non-signatories have the same objective as the proposed theory. The existing non-signatory theories have sought to address the inadequacies of international arbitration with regard to complex multiparty commercial transactions by purporting to extend arbitration agreements to non-signatories. The proposed unifying theory addresses the same fundamental problem, but rather than pursuing, often elusive and artificial, evidence of constructive consent, it focuses on commercial reality and the role of non-signatories in the actual transaction. For these reasons, the proposed theory offers a distinct improvement on resolving international commercial disputes involving non-signatories.

This article has sought to demonstrate that by developing a unifying theory on non-signatories with a single test under a single set of rules international arbitration may become better equipped to accommodate the needs of contemporary international commerce. It may be that the suggested test for tribunals to assume jurisdiction needs further refinement. Nevertheless, it is

138 See for example, the seminar book of Fouchard, Gaillard and Goldman on International Commercial Arbitration (Kluwer 1999), which canvasses the development of transnational substantive rules in international arbitration.

139 See the seminal article by Jan Paulsson, "Delocalization of International Commercial Arbitration: When and Why It Matters" 32 Int'l \& Comp. L.Q. 53, 59 (1983). 
necessary to begin to consider that, as the article has suggested, the traditional bilateral paradigm of arbitration and consent-based analyses may have been outgrown by the realities of international multiparty and multi-contract transactions. ${ }^{140}$

140 Strong above (note 8) 995. 